\title{
Role of Stock Exchanges in Economic Development of Uzbekistan
}

\author{
Ulugbek Khalikov ${ }^{1}$ \\ ${ }^{1}$ Researcher at Tashkent Financial institute, Uzbekistan \\ Correspondence: Ulugbek Khalikov, Researcher at Tashkent Financial institute, Uzbekistan. \\ E-mail: bu_exp@yahoo.com
}

Received: March 31, 2016

doi:10.5539/ibr.v10n1p172

\author{
Accepted: December 20, 2016 Online Published: December 23, 2016 \\ URL: http://dx.doi.org/10.5539/ibr.v10n1p172
}

\begin{abstract}
The paper is devoted to study the contemporary role of investments to economic development in the context of Uzbek stock exchange. The comparative analysis of economic development and stock market trends in Uzbekistan, Kazakhstan and Russia for the period of 2000-2015 are conducted using documentary analysis, quantitative and qualitative analysis, and other statistical methods of research.

The results reveal that Uzbekistan has made notable change in regulation and improvement of investment climate and has stable economic development trends for the studied period. However, Stock market development in Uzbekistan remains weak and recent government effort to accelerate privatization is expected to boost the market and support foreign investments attraction.
\end{abstract}

Keywords: investments, growth, stock, exchange, Uzbekistan, market

\section{Introduction}

The importance of investment for economic growth has long been recognized. Investment in a nation's capital stock may contribute to increased productivity and hence stronger economic growth in the medium term. This holds true for both the formation of tangible fixed assets such as machinery and equipment, and intangible assets originating from investment in research and development (Kolev, A., Tanayama, T., \& Wagenvoort, R., 2013). Furthermore, theory and evidence imply that better developed financial systems ease external financing constraints facing firms, which illuminates one mechanism through which financial development influences economic growth (Levine, R., 2005). It should come as no surprise then that investment is suppressed when finance is unavailable, and that economies perform badly when financial sectors underperform. In contrast, a well-functioning and developed financial sector can boost economic growth.

According to a recent study by the European Commission this stable long-term relationship between investment and economic activity broke down in 2008. Since the beginning of 2008 investment rates have declined appreciably across the EU-27. This decline has been larger than could have been predicted on the basis of the historical relationship between investment and GDP. There, gross fixed investment relative to GDP has declined by about 7 percentage points compared with the 15-year pre-financial crisis average (EC, Quarterly Report on the Euro Area. 2013).

The research shows that falling demand for natural resources and collapse of oil prices combined by recent monetary policies in advanced economies have undermined the growth prospects of developing countries (Stiglitz, J., \& Rashid H., 2016). As a result all Central Asian countries including Uzbekistan have faced the challenges of global and regional negative factors.

The objective of this publication is to provide an analysis of investment in connection to economic growth. Problems in current investment climate and the ways to support the stock exchange market in Uzbekistan were researched in the context of attraction of foreign investments. To reach this goal economic growth, investments, stock exchange performance in Uzbekistan is studied in comparison with other emerging countries such as Russia and Kazakhstan.

We begin by discussing current development trends, investment climate, and analyze the structure and main indicators of Uzbek stock exchange before assessing the impact of the government regulation.

\section{Overview of Investment Climate in Uzbekistan}

According to results of the research Uzbekistan remains among the top ten fastest growing countries with the 
annual GDP growth rate of 8.0\% (Burkhanov, U., Maitah, M., \& Amonov, Kh., 2015) and outperforming its oil dependent neighbors such as Kazakhstan and Russia (figure 1).

The government of Uzbekistan declares that attracting foreign direct investment is core priority and there were more than 50 legislative documents issued to accelerate and coordinate investment processes. The legislation provides a wide range of guarantees to investors, including: protection against discrimination, protection from harm caused by retroactive implementation of legislation, protection from interference by the state in the economic activity of foreign investors, and protection from any changes in legislation that worsens foreign investment conditions (Burkhanov, U., \& et. al., 2015).

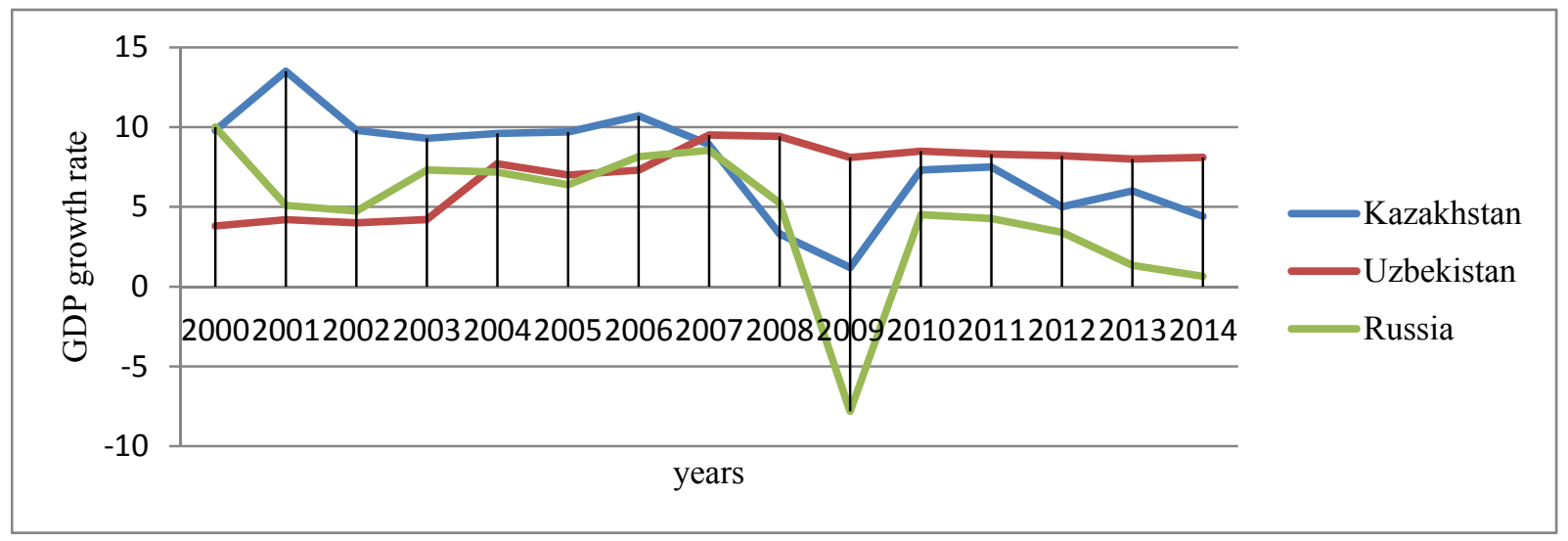

Figure 1. GDP growth rate of Uzbekistan, Kazakhstan and Russia ${ }^{1}$

Recently, Uzbekistan has made notable improvement in investment climate and consequently in World Bank's Doing Business Index is ranked is in Top-10 economies showing the most in performance indicators in 2014/15 (table 1)

Table 1. The changes of Uzbekistan's indicators in World Bank's Doing Business Index ${ }^{2}$

\begin{tabular}{|c|c|c|}
\hline \multirow[b]{2}{*}{ Years } & \multicolumn{2}{|c|}{ Overall ranking } \\
\hline & Position & Change $(+/-)$ \\
\hline DB 2015 & 141 & $\Delta 5$ \\
\hline DB 2016 & 87 & $\Delta 54$ \\
\hline Indicators & DB-2016 & $+/-$ \\
\hline Starting a Business & 42 & $\Delta 22$ \\
\hline Registering Property & 87 & $\Delta 26$ \\
\hline Getting Credit & 42 & $\Delta 63$ \\
\hline
\end{tabular}

The study shows that the overall business climate may be described as stable, but with a potential for rapid growth in the event of more radical reforms towards privatization and reduced state regulation of the economy.

Uzbekistan could keep stable rates of capital investments during and post financial-crisis period, which allowed beginning to modernize of industry and diversify of the economy. In contrast, the rates of capital investments in Kazakhstan were more volatile and reduced to about $24 \%$ of GDP in 2014 , comparing its peak period (35\% in 2007). Also, Russian economy badly hurt by Western sanctions fell behind to Uzbekistan with about $20 \%$ of GDP in 2014 against 25\% of GDP in Uzbekistan for the same time (figure 2).

However, the Western sanctions to Russia (which is the main trading partner of Central Asian countries) severely damage foreign currency inflows to Uzbekistan and government plans to fill this gap through massive privatization program. The figure 3 shows increasing volume of FDI in Uzbek economy. In the absence of reliable data on portfolio of foreign investments the figure represents general positive trend.

\footnotetext{
${ }^{1}$ Prepared by the author on the bases of www.theglobaleconomy.com data.

${ }^{2}$ Author's calculations based on the World Bank Doing Business Index Report, 2016.
} 


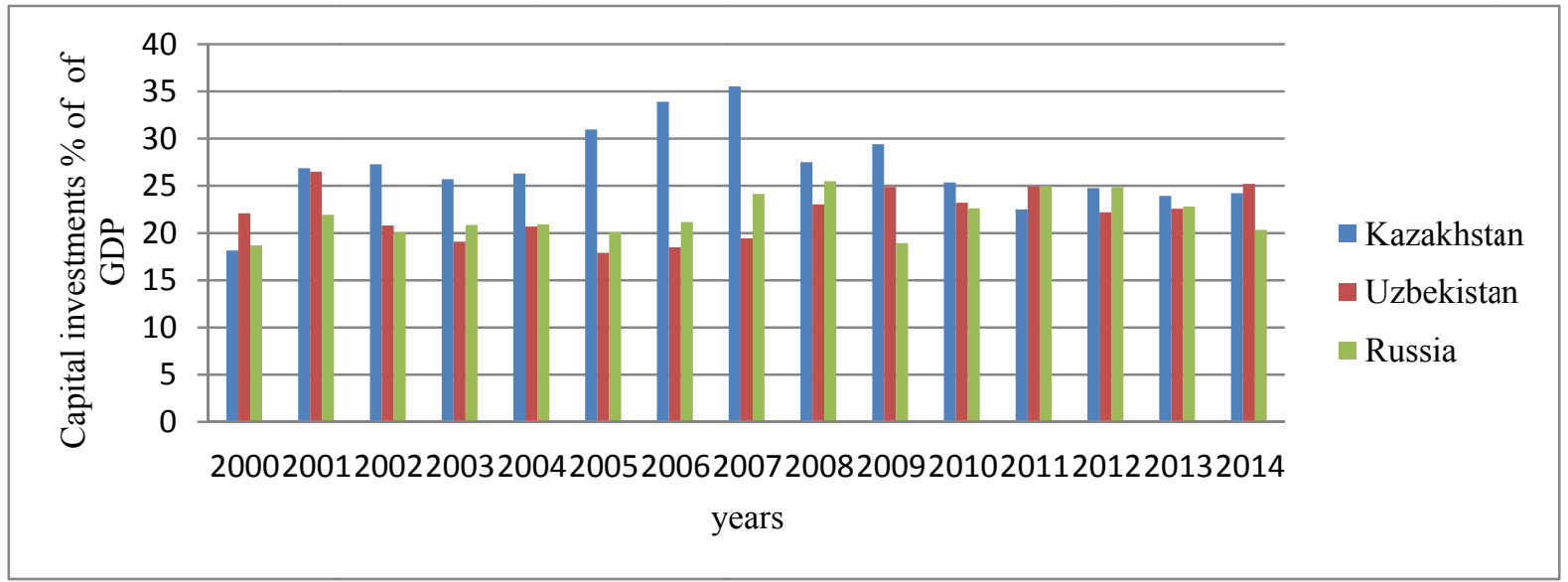

Figure 2. Capital investments in Uzbekistan, Kazakhstan and Russia ${ }^{3}$

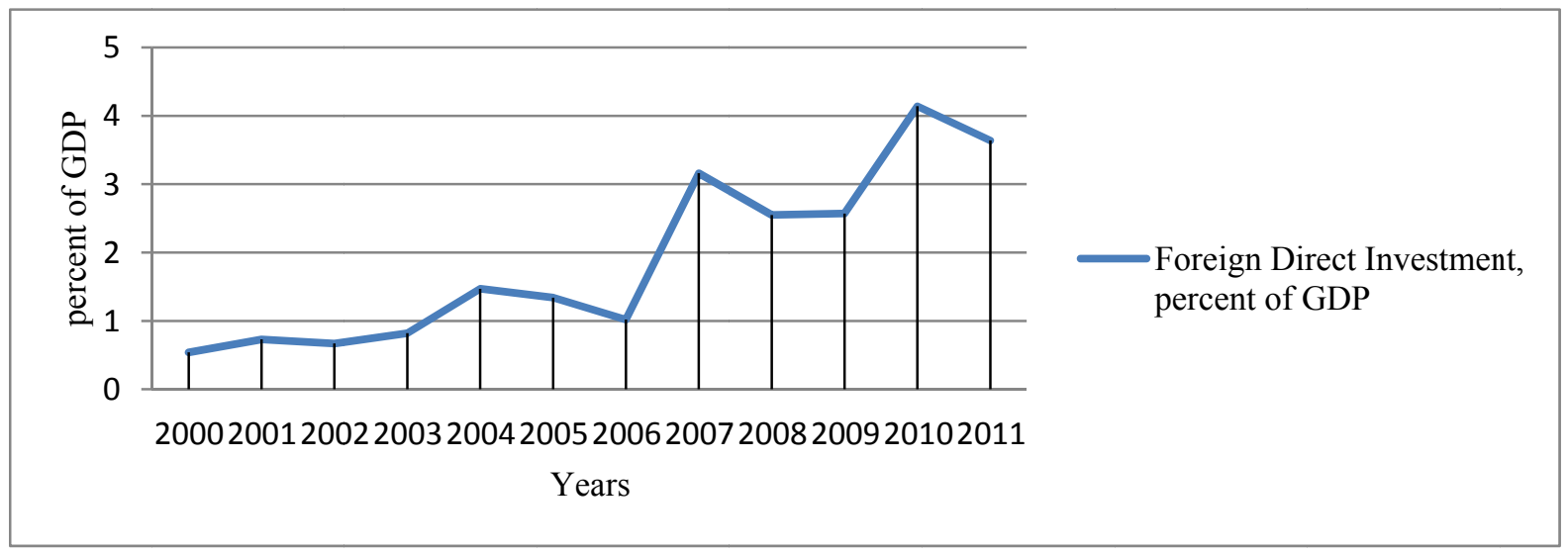

Figure 3. Foreign direct investments in Uzbekistan ${ }^{4}$

As of 2016 the government started new privatization program aimed reducing the level of state share in the economy to strategically and economically reasonable levels (figure 4). According to the state program in 5 years more than $85 \%$ of GDP should be generated by private sector.

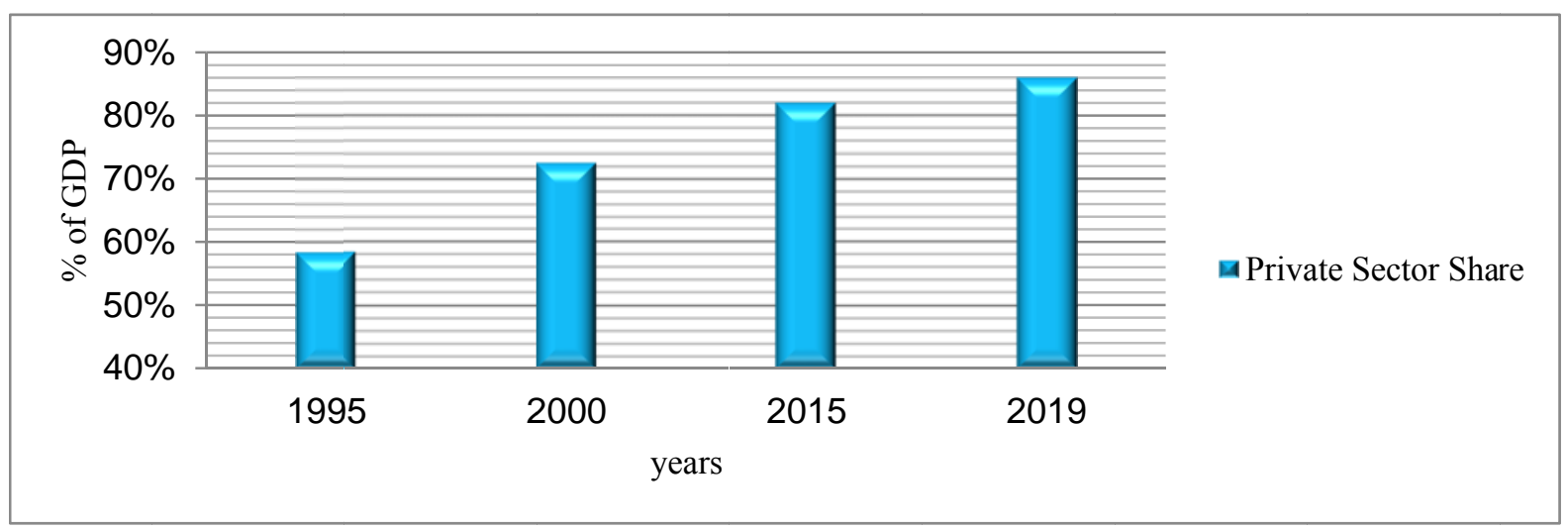

Figure 4. Increasing private sector share in Uzbekistan ${ }^{5}$

The program includes privatization of 1247 state enterprises and assets, including 512 enterprises - at "zero cost"

\footnotetext{
${ }^{3}$ Prepared by the author on the bases of www.theglobaleconomy.com data.

${ }^{4}$ www.theglobaleconomy.com/Uzbekistan

${ }^{5}$ The Ministry of Finance of the Republic of Uzbekistan data
} 
and sale of the state share in 68 large-scale enterprises ("Ferghana-azot", "Navoi-azot", "Photon" "Dzijak accumulator plant", "Qizilkum cement", "Urgench excavator plant”, etc.) only for our strategic foreign investors.

\section{Analysis of Uzbek Stock Market}

The stock exchange in Uzbekistan is in the stage of formation. With the recent legislative changes to improve regulation of corporations and corporate governance government want to accelerate reforms and decrease state participation in economy.

Stock market capitalization of about 50 percent of GDP and more is an indication of a well-developed stock market (www.theglobaleconomy.com). Yet, in most countries the stock market almost does not exist and it's close to zero.

The stock market capitalization is calculated as the number of shares traded on the stock exchange times their prices. It is a measure of the size of the stock market in the country. It is usually reported as percent of GDP so that we can evaluate the size of the stock market relative to the size of the economy.

The figure 5 compares stock market capitalization rate of Uzbekistan, Kazakhstan and Russia. However, the data for Uzbekistan provided only till 2006 and the stock market capitalization rate is about 4\% of GDP which is still remains low comparing the other two (OECD, 2012).

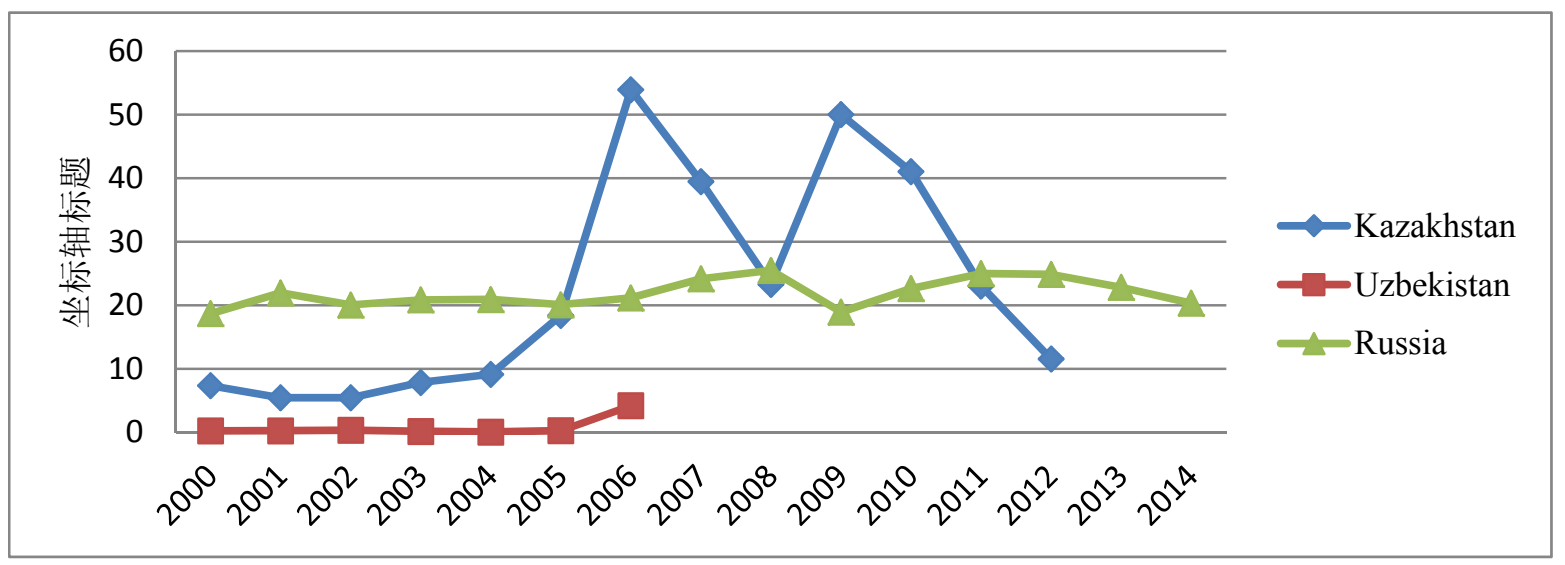

Figure 5. Stock market capitalization in Uzbekistan ${ }^{6}$

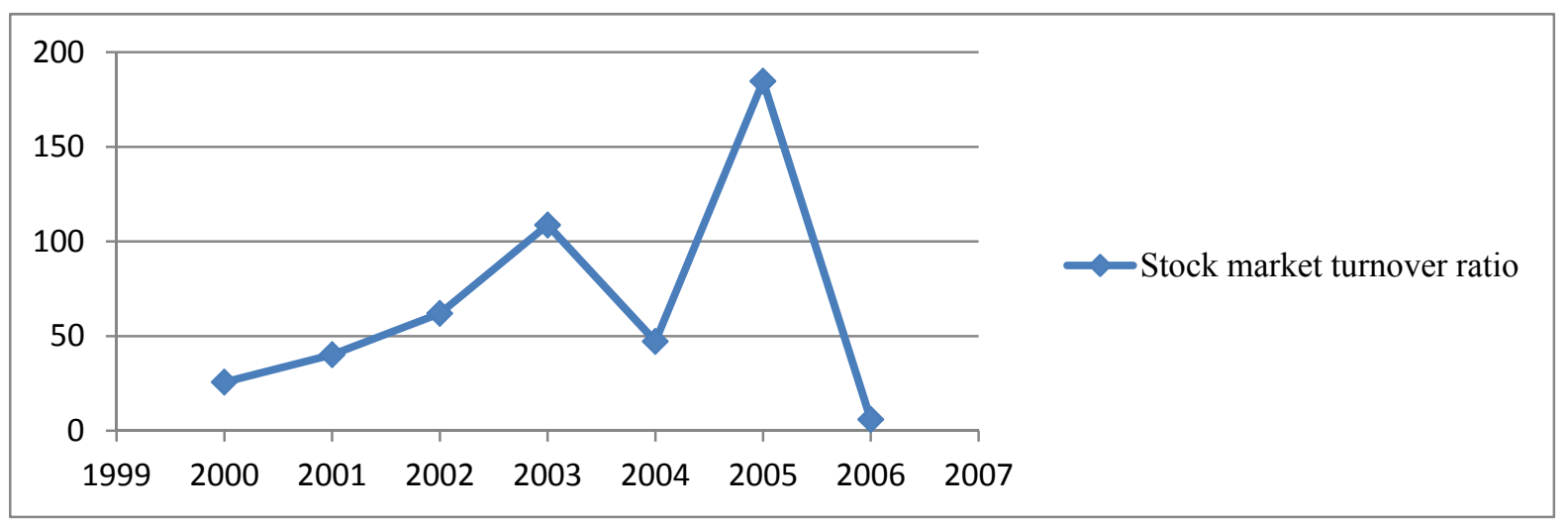

Figure 6. Stock market turnover ratio, Uzbekistan ${ }^{7}$

Among studied countries the highest capitalization rate in Kazakhstan, but high volatility and recent sharp decline can be seen from the figure. Russia stock market capitalization with average 20\% of GDP remains more stable during the studied period.

The low capitalization rates during 2000-2006, in Uzbekistan can be explained by declining stock market turnover ratio (figure 6). Lack of data for the recent years makes impossible to conduct analysis for this market indicator.

${ }^{6}$ Prepared by the author on the bases of www.theglobaleconomy.com data

${ }^{7}$ www.theglobaleconomy.com/Uzbekistan 
The stock market could be composed of a few large companies whose shares are seldom traded and large stock market capitalization does not necessarily mean that the stock market is active.

The results of Uzbek government effort to revive the market it shows some signs of improvement. For instance, at the end of 2015 the number of concluded deals at the Republican Stock Exchange "Tashkent" has reached a record high in the last five years - 2794 deal, which is more than three times the figure for the same period in 2014 (893 deals) (Stock Exchange Review, 2015). The steady rise can be seen in total market turnover (figure 7) which is reached in $161 \mathrm{bln}$. UZS in 2015.

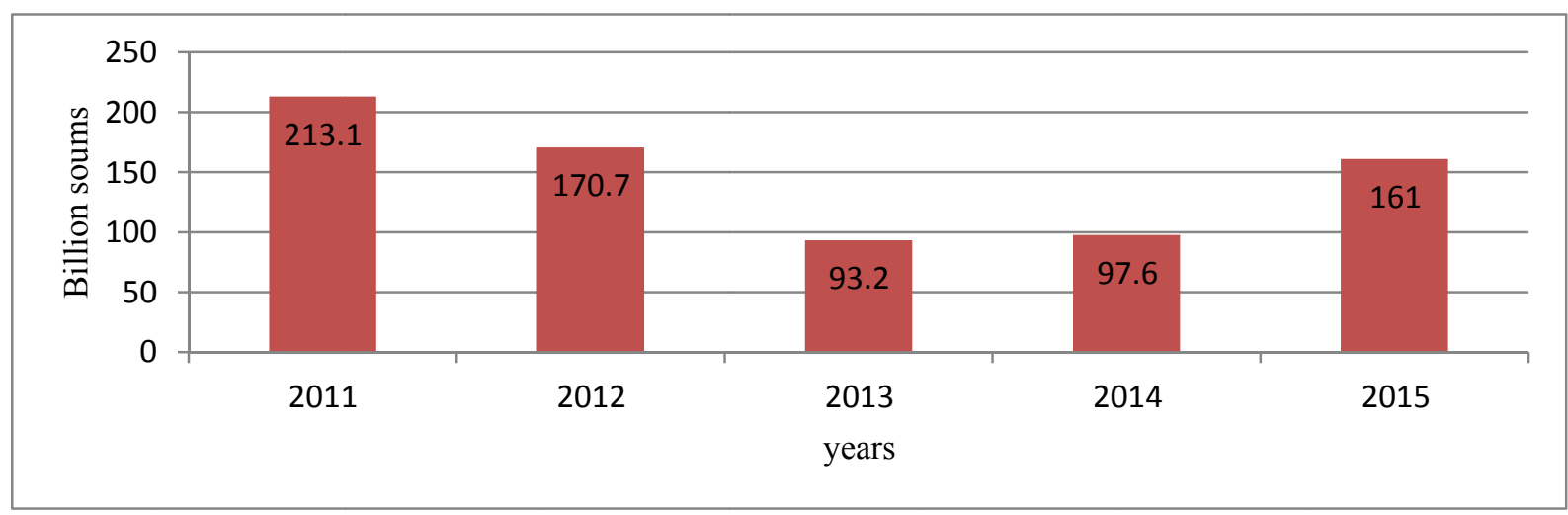

Figure 7. Deals concluded in stock market, bln. $\mathrm{UZS}^{8}$

In addition, the other positive indicator of stock market can be seen in increased number of listed companies in Uzbekistan from the beginning of 2015. The 128 new companies were included in the quotation list, and at the end of 2015 their number reached to 261 (figure 8). The data for Uzbekistan is not provided for 2008-2010, however the figure presents the positive trend comparing for other studied stock markets.

The analysis of quality indicators of listed companies shows that the 24 joint stock companies meet the requirements of category "A", 28 of them meet the requirements of category "B", 177 - in category "C" and 32 in category "P" (Stock Exchange Review, 2015). Among the listed companies - commercial banks, insurance companies, enterprises of oil and gas, production of construction materials, agriculture, energy, metals and others.

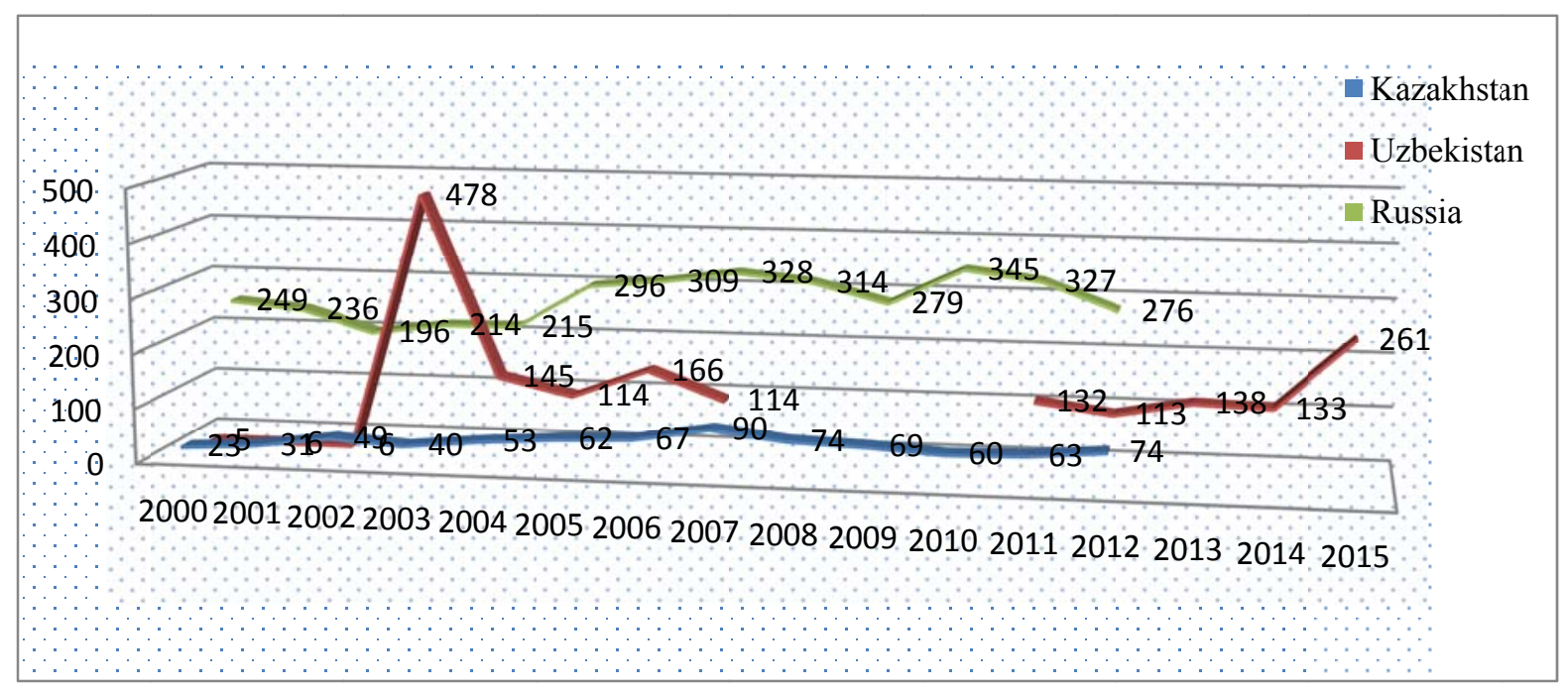

Figure 8. Number of listed companies of selected countries ${ }^{9}$

The study reveals that in the structure of total exchange turnover secondary market securities is dominated $58.8 \%$

${ }^{8}$ Stock Exchange Review, 2015

9 Prepared by author on the basis data from Stock Exchange Review, 2015 and www.theglobaleconomy.com/Uzbekistan 
of the total turnover or 94.7 bln.UZS (Figure 9), or the absolute turnover of this market rose almost 3 times in comparison with the year 2014 (32.2 bln.UZS).

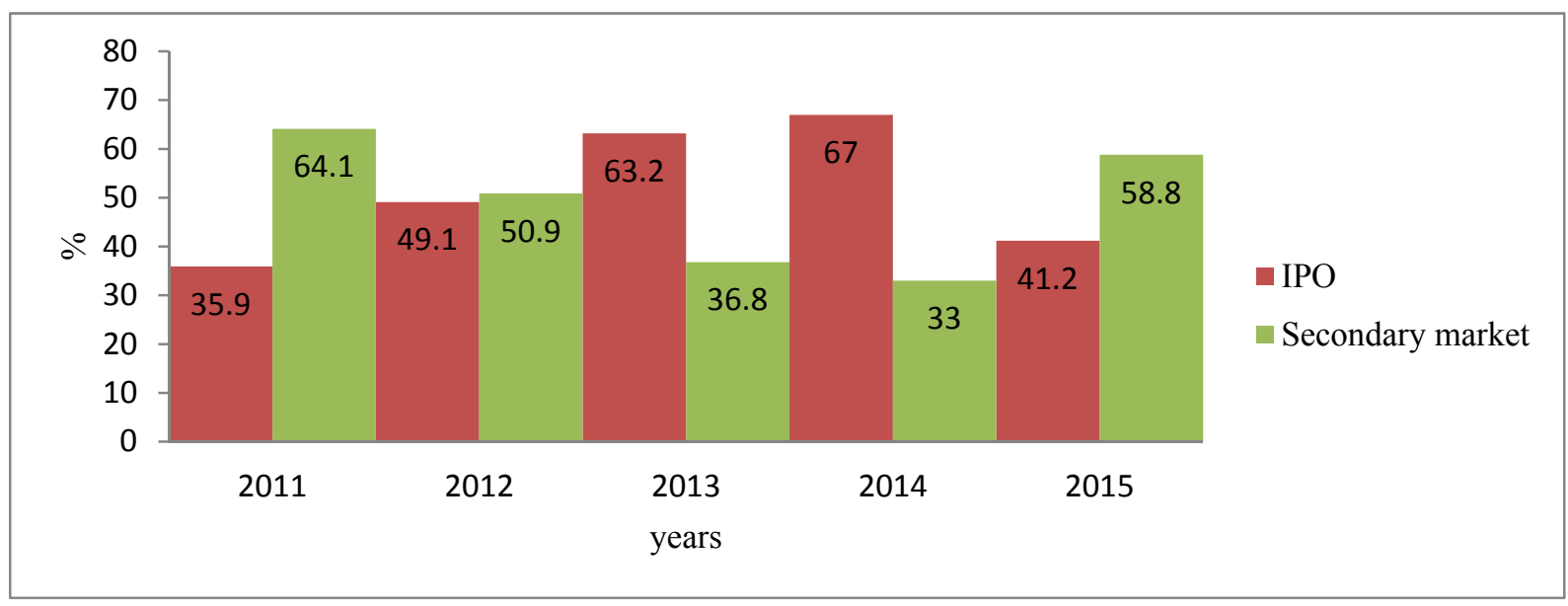

Figure 9. Stock market structure, Uzbekistan ${ }^{10}$

The analysis of stock exchange indices from the categories of investors, it should be noted that the volume of investments of legal entities is a major part of the exchange turnover $-95.0 \mathrm{bln}$. UZS or $81.8 \%$ of total turnover. At the same time, a slight decrease in investment activity from individuals, whose share in the stock exchange turnover amounted to $18.2 \%$, or $18.6 \mathrm{bln}$. UZS.

Analysis of IPO market results that 7 out of top 10 IPO are made by banks and this situation can be explained by remaining high interest from investors to this sector (table 2). For instance, 93.1\% of investors preferred banks securities in 2015, while this data for 2014 was $93.4 \%$.

Table 2. Top 10 IPO's in Uzbekistan in $2015^{11}$

\begin{tabular}{ccc}
\hline Name of company & Industry & IPO volume, bln. UzS \\
\hline Ipoteka-bank & Banking & 56.5 \\
InFinBank & Banking & 15.7 \\
Aloqabank & Banking & 13.7 \\
Trastbank & Banking & 13.1 \\
Asia Alliance Bank & Banking & 12.6 \\
O"zsanoatqurilishbank & Banking & 11.7 \\
Qo'qon yog'-moy & Food industry association & 6.4 \\
Kapitalbank & Banking & 5.0 \\
Kogon Yog-Ekstraksiya zavodi & Food industry association & 5.0 \\
Turonbank & Banking & 4.1 \\
\hline
\end{tabular}

The study of sectorial structure of stock markets is also important, because it's a good indicator showing how stock market represents the whole economy. Thus, the study considers the sectorial structure of Uzbek stock exchange in 2015 (figure 10). It reveals that bank securities were the most traded assets for the 2015 totaling $87.8 \%$ of all trade, followed by agroindustry sector with $7 \%$. And, all other sectors of economy even could not made $5 \%$ of trades. This evidence's previous studies (Burkhanov U., Maitah M. \& Amonov Kh., 2015) that the economy lacks of well diversification and need further reforms towards to market liberalization.

\footnotetext{
${ }^{10}$ Stock Exchange Review, 2015

${ }^{11}$ Stock Exchange Review, 2015
} 


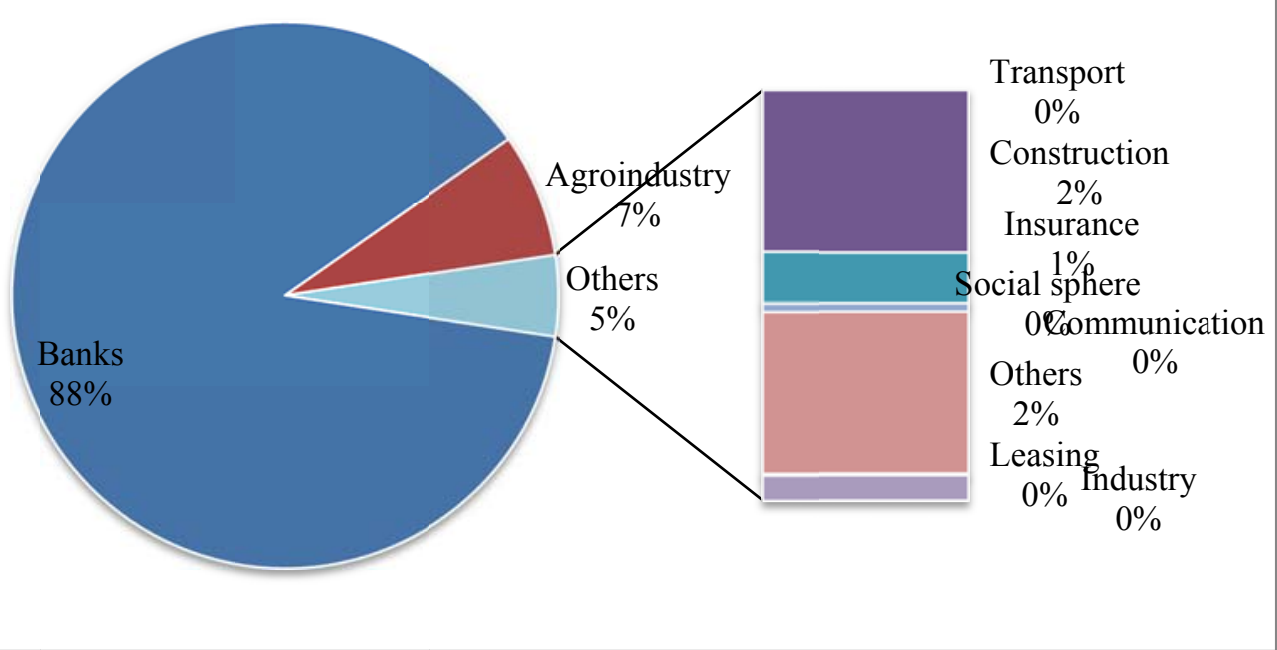

Figure 10. The sectorial structure of stock market, Uzbekistan ${ }^{12}$

\section{Foreign Experience of Investment Attraction}

The research reveals that (Review.uz, 2016) to support stock exchange the priority is given to foreign investors in privatization program. According to presidential decree dated March 19, 2012 Korea exchange (KRX) is expected to become a shareholder of Tashkent RSE in 2014 by acquiring 25 percent in the equity capital. Meantime, shareholders of RSE are local largest commercial banks and state (www.wikipedia.org).

In this context studying advanced foreign experience is worthwhile in developing national strategy. The increased role of stock exchanges to attract foreign investments can be seen in one of the fast growing economies, in South Korea.

According to the study at the end of 2011, foreign ownership of domestic exchange-listed shares accounted for KRW 351.5 trillion, just over $30 \%$ of the total market capitalization of KRW 1.148 trillion (figure 11). The domestic stock market was first opened to foreign investors in 1992. The percentage of domestic shares owned by foreign investors steadily climbed until it hit a peak of $42.1 \%$ in July of 2004. However, owing in large part to the 2008 financial crisis, rallies of equities in emerging markets, and global investor portfolio adjustments, foreign ownership has been on a generally downward trend as a percentage of the market, starting in 2005 . Nevertheless, for past few years foreign ownership had increased again at a slower pace (www.kofia.or.kr).

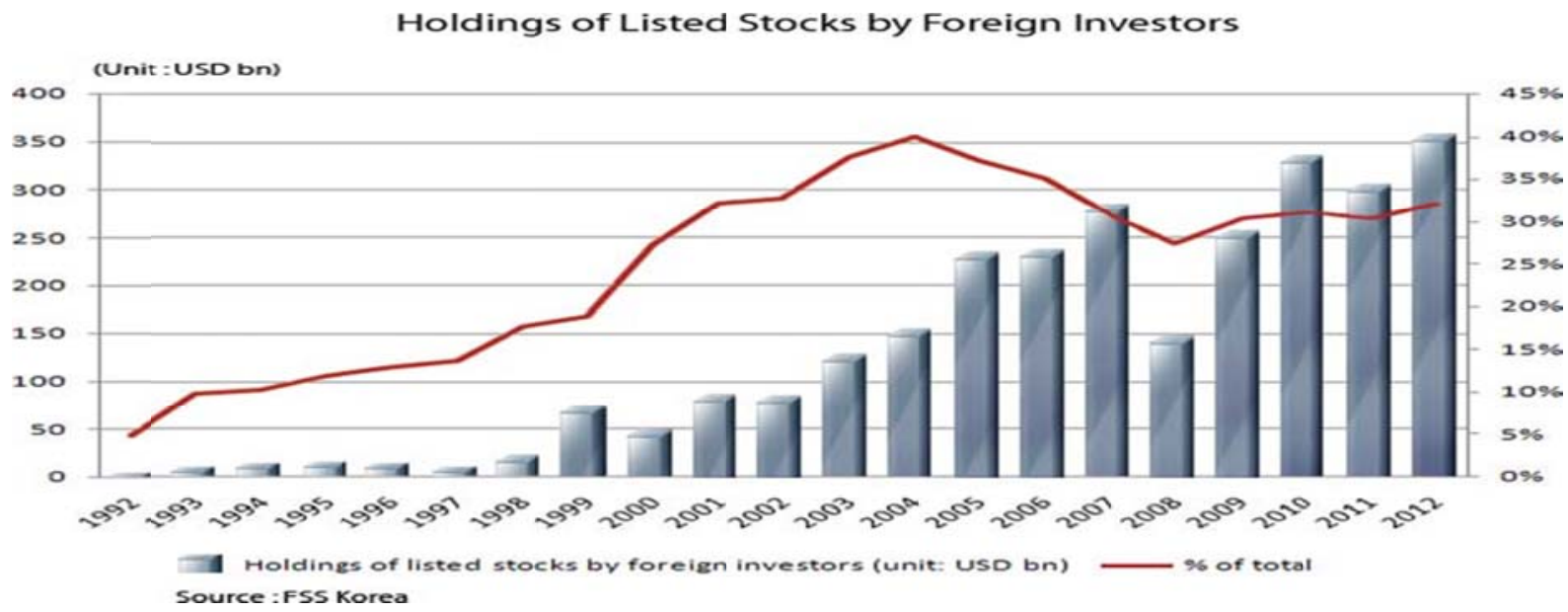

Figure 11. Holdings of listed stock by foreign investors, South Korea

\footnotetext{
${ }^{12}$ Stock Exchange Review, 2015
} 
Further, the analysis of South Korean market shows (figure 12) slight decline in the number of registered foreign investors starting from 2010, however, holdings of listed stocks were increased from about $30 \%$ in 2010 to $33 \%$ in 2012.

Number of Registered Foreign Investors

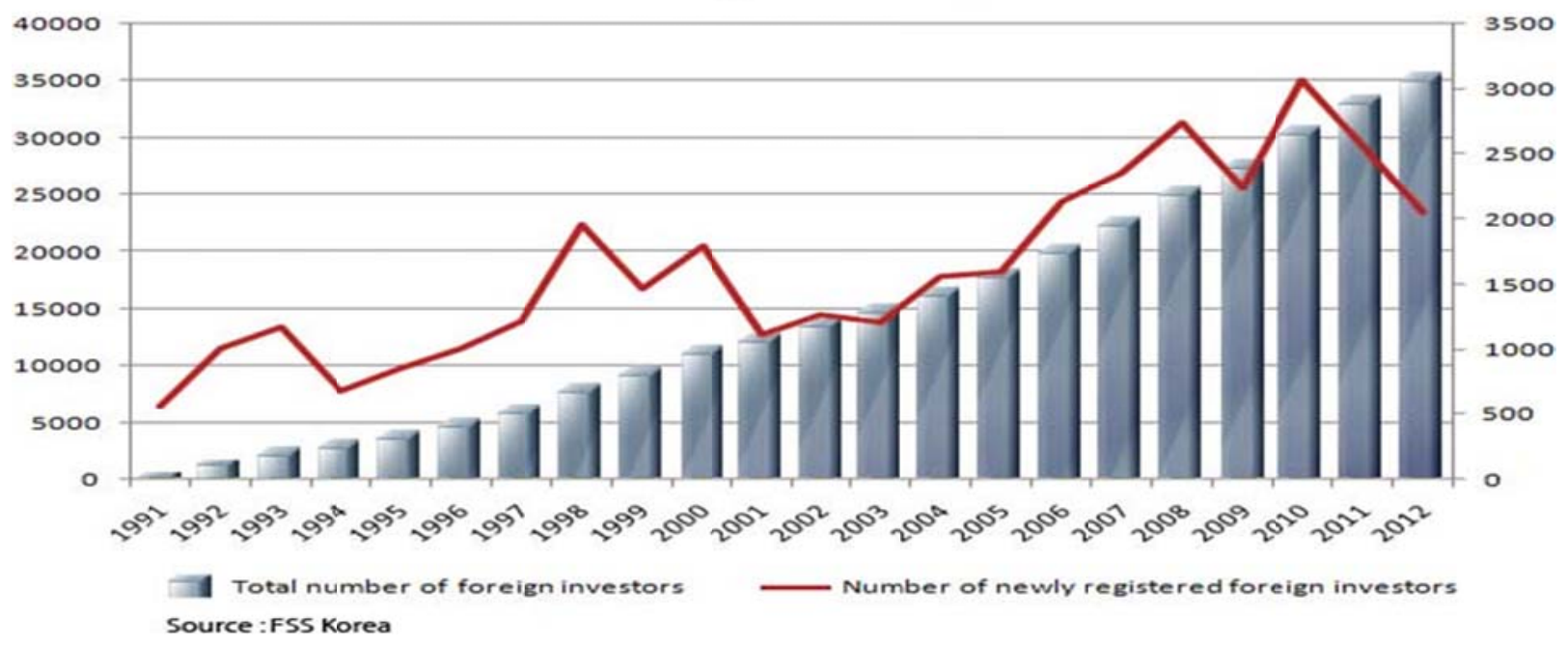

Figure 12. Number of registered foreign investors, South Korea

It is also worth knowing that the quantitative easing in the US and Europe's LTRO efforts spurred a shift in liquidity toward capital markets, which will possibly lead to a worldwide stock rally (Stiglitz J. and Rashid H., 2016).

The results of other study show that starting from 2013 Russian stock indicators climbed down reflecting to low oil prices and western sanctions (Jain S., 2015). The Russian government is attempting to recover stock market loss by attraction of foreign investors, which planned to take place through the change of dividend policy of the country's leading state corporations as well as implementation of other regulation measures. According to a recent change, all the country's leading state-owned companies and corporations will use the new dividend policy, which involves payment of dividends in the amount of not less than $25 \%$ of their annual profit (Gerden E., 2015).

According to analysts, so far, the majority of foreign investors, which suspended their activities in Russia due to the crisis, have decided to return to the market. The ever growing interest is observed in the case of a wide range of foreign investors from hedge funds to large investment funds. Overall, the biggest activities of foreigners in the Russian market are currently observed in the segments of corporate bonds, as well as government bonds and equities.

Devaluation of the Russian currency - Rouble against the US dollar, euro and other currencies, (which are used for commodities' trading), has made many Russian industrial sectors, such as agriculture, processing, textiles, petrochemicals, more competitive and, therefore, more attractive to foreign investors. In addition, many assets in the Russian market are currently undervalued (www.globalinvestormagazine.com).

\section{Conclusion}

The study is motivated by the global and regional challenges developing markets have faced in recent years. This article provides empirical evidence on economic development, investment climate and stock market in Uzbekistan. Despite the stable economic growth rates and recent improvement (upgrading to 87 position in global ranking) in WB doing Business index, Uzbekistan needs rapid reforms towards to market liberalization. The comparative analysis of stock markets in Uzbekistan, Kazakhstan and Russia for the period of 2000-2015 is resulted, that Uzbek stock market remains weak and recent government effort to accelerate privatization is expected to boost the market and support foreign investments attraction. However, as recent study revealed that positive trend with increasing number of listed companies and revitalized trade in stock exchange can be seen in preliminary results of reforms.

In sum, the research attempts to assess investment environment and to provide empirical evidence of stock market insides in Uzbekistan and reveals existing problems for future research. 


\section{References}

Burkhanov, U., Allaberganova, H., \& Khudoykulov, K. (2015). Problems of attraction of foreign direct investments in Uzbekistan. Spanish Journal of Rural Development, VI(1-2), 59-64. https://doi.org/10.5261/2015.GEN1.07

Burkhanov, U., Maitah, M., \& Amonov, K. (2015). The Problems of Investment Climate in Uzbekistan. Review of European Studies, Canadian Center of Science and Education. https://doi.org/10.5539/res.v7n11p232

European Commission. (2013). Quarterly Report on the Euro Area, 12(2). http://ec.europa.eu/economy_finance/publications/qr_euro_area/2013/pdf/qrea2_en

Gerden, E. (2015). Foreign investors return to Russia. http://investorintel.com/market-analysis-intel/foreign-investors-return-to-russia/

Jain, S. (2015). Must-know threat: Recession looms over Russia. http://marketrealist.com/2015/01/must-know-threat-recession-looms-russia/

Kolev, A., Tanayama, T., \& Wagenvoort, R. (2013). Investment and Investment Finance in Europe. Economics Department of European Investment Bank. Published by the European Investment Bank.

Levine, R. (2005). Finance and growth: theory and evidence. Handbook of economic growth. Volume 1A. Brown University and the NBER. Elsevier. https://doi.org/10.1016/S1574-0684(05)01012-9

Stiglitz, J., \& Rashid, H. (2016). How can developing countries stop their capital draining away? https://www.weforum.org/agenda/2016/02/how-can-developing-countries-stop-their-capital-draining-away

Stock Exchange Review. (2015). (the original of material is in Russian: Birjivie obozrenie, za dekabr, 2015. Obzor birjevih za 2015 god).

\section{Web Pages}

OECD. Capital Markets in Eurasia: Two decades of reform. Istanbul, 2012.

www.oecd.org/daf/ca/CapitalMarketsinEurasia.pdf

Review.uz. Uzbekistan reduces prices for state assets sale for foreign investors. 25.03.2016. http://review.uz/index.php/novosti-main/item/7763-uzbekistan-snizhaet-tseny-na-realizuemye-inostrannym-inves toram-gosaktivy

https://en.wikipedia.org/wiki/Tashkent_Stock_Exchange

http://www.theglobaleconomy.com/Uzbekistan/

Ministry of Finance of the Republic of Uzbekistan. https://www.mf.uz/en

Foreign Investors Attracted to Korean Market. http://eng.kofia.or.kr/wpge/m_49/investment/foreign.do

Russia market "significantly undervalued". 28 March 2014.

$\mathrm{http}: / / \mathrm{www} . g l o b a l i n v e s t o r m a g a z i n e . c o m / A r t i c l e / 3324771$

World Bank Doing Business Index Report, 2016. www.doingbusiness.org

\section{Copyrights}

Copyright for this article is retained by the author(s), with first publication rights granted to the journal.

This is an open-access article distributed under the terms and conditions of the Creative Commons Attribution license (http://creativecommons.org/licenses/by/4.0/). 